EVS25

Shenzhen, China, Nov 5-9, 2010

\title{
Design of Forced Air-cooling Structure for Elevated Temperature PEMFC
}

\author{
Xiaoliang Zheng ${ }^{1,2}$, Daijun Yang ${ }^{1}$, Kan Tao ${ }^{2}$, Hao Zhang ${ }^{1,2}$ and Jianxin Ma ${ }^{1,2, *}$ \\ ${ }^{1}$ School of Automotive Studies, Tongji University, 4800 Cao'an Road, Shanghai, 201804, P R China \\ jxma@tongji.edu.cn \\ ${ }^{2}$ Clean Energy Automotive Engineering Center, Tongji University, 4800 Cao'an Road, Shanghai, 201804, P R China
}

\begin{abstract}
Proper operating temperature range and homogenous temperature distribution are important to proton exchange membrane fuel cell (PEMFC). For the elevated temperature PEMFC water is not suitable to be used as coolant due to high operating temperature. Instead, air can be chosen as coolant because of the relative large temperature difference between fuel cell itself and the ambient air. In this paper, four types of forced air-cooling modes for elevated temperature PEMFC were discussed, and influences of other factors such as cooling air inlet velocity and thermal conductivity of bipolar plate material and fins on heat dissipation and temperature distribution were investigated. Three-dimensional computational fluid dynamics (CFD) method was employed to investigate fluid flow and heat transfer in the elevated temperature PEMFC on a $250 \mathrm{~cm} 2$ single cell level. The temperature distribution fields on the active area of MEA were obtained and compared. One optimized mode, with suitable cooling air inlet velocity and bipolar plate material, was determined for future experimental study.
\end{abstract}

Keywords:Elevated temperature, PEMFC, Air-cooling, Cooling structure, CFD, Temperature distribution.

\section{Introduction}

As an energy convertor, proton exchange membrane fuel cell (PEMFC) has many advantages, including clean, efficient and high power density, etc., and it is regarded as an ideal power source for vehicles in the future[1,2].

Operating temperature is a critical factor for PEMFC since it greatly influences the performance and durability of the PEMFC. The ordinary operating temperature of a PEMFC is around 60-80oC. Recent research has confirmed that PEMFC operated at an elevated temperature can bring many benefits, e.g. enhanced electrochemical kinetics for both electrode reactions, simplified water management, and increased $\mathrm{CO}$ tolerance[3]. However, if the operating temperature is too high, it may lead to degradation on membranes, catalysts layers (CLs) and gas diffusion layers (GDLs). Since energy efficiency of fuel cell is approximately $50 \%$, a kW-class PEMFC stack generates also the same amount of heat. Therefore, it is important to remove the excessive heat and keep PEMFC operating in a proper temperature range. Furthermore, a homogeneous temperature distribution in the active area is also very important for PEMFC. It can increase the kinetic rates at reaction sites and reduce the ohmic losses in the electrolyte [4]. At the same time the electrolyte mechanical strength can also be improved [5]. So a proper cooling structure must be designed to maintain 
the internal temperature in a suitable range and achieve homogeneous distribution.

For PEMFC operating at elevated temperature, i.e. $90-950 C$, water is no longer suitable to be chosen as coolant because the operating temperature is nearly reaching water's boiling point. Thermal oil and air were considered to be chosen as cooling mediums for elevated temperature PEMFC. Till now there are only limited literatures published on high temperature PEMFC stack [6-11], most of which chose thermal oil as coolant because of its higher boiling point and chemical stability at elevated temperature. However, the employment of thermal oil is also problematic. The leaking of thermal oil into the electrode will be lethal to the stack, and leaking to the outside environment will lead to pollution. Therefore the coolant loop should be properly separated from the bipolar plates. And then the stack structure became more complicated and the cost increased.

Due to the enlarged temperature discrepancy between PEMFC and the ambient air, air can be considered as an optional coolant. Instead of separated and complicated coolant circuit, simplified cooling system or structure can be used, e.g., cooling fins can be added by the bipolar border and then no pump is necessary and disadvantages of oil leakage can be avoided.

In the present work, three-dimensional computational fluid dynamics (CFD) method was employed to investigate fluid flow and heat transfer in the PEMFC on a single cell level. The temperature distributions in the active area by virtue of four types of air-cooling modes were obtained respectively, and then compared.

\section{Mathematical modeling}

\subsection{Geometric model}

The general (or typical) geometric model of the PEMFC is presented in Figure 1. As shown in Figure 2, the geometric model consists of GDLs, bipolar plate, fins, H2/Air flow channels and cooling air flow channels. The fins are designed as elongated parts of the traditional bipolar plate. Cooling air flows over the fins and takes away the heat.

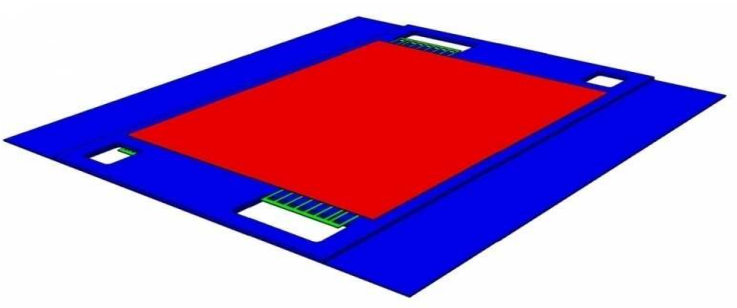

Figure 1 Typical geometric model of PEMFC
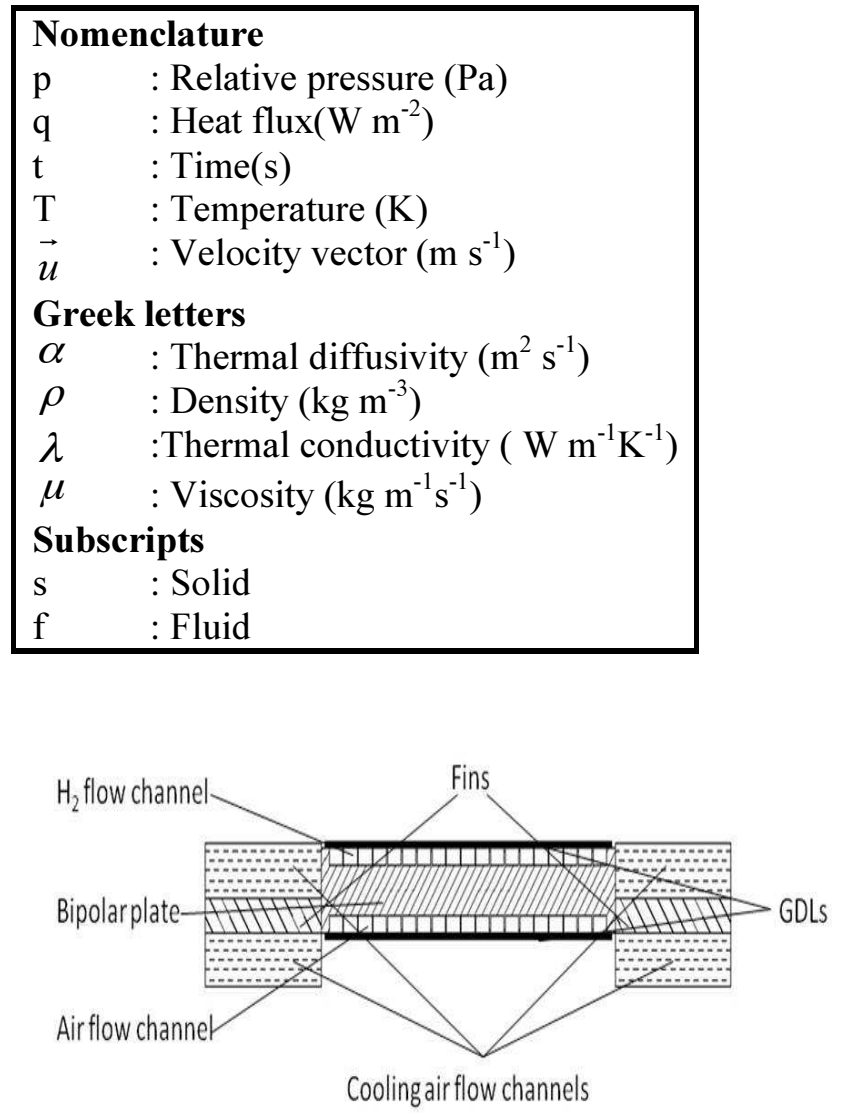

Figure 2 Structure of the typical PEMFC geometric model

\subsection{Assumptions}

For modeling purposes, following assumptions were made:

- The operating condition is steady;

- All gases are treated as ideal gas;

- The incompressible air/ $\mathrm{H}_{2}$ are used as working fluid;

- Because of lower velocity of gases in flow channel, these zones are regarded as laminar zone;

- The thicknesses of the membrane and catalyst layer are ignored;

- The efficiency of the PEMFC is 50\%;

- The heat source is located on the top surface of GDL, which doesn't contact with the bipolar plate, and it generates heat homogeneously;

- The GDL is porous.

\subsection{Governing equations}

The model in this contribution refers to fluid flow and heat transfer in a steady state, and the gravity influence 
can be ignored.

For the fluid flow, the governing equations are described as follows:

Continuity equations

$$
\nabla \square(\rho \vec{u})=0
$$

Momentum equation

$$
\nabla \cdot(\rho \vec{u} \vec{u})=\nabla \cdot(\mu \nabla \vec{u})-\nabla p
$$

In this model, heat transfer between the forced convection in gases flow and solid heat conduction in the bipolar plate, fins and GDLs are coupled. Therefore the equations for heat transfer in solid and fluid regions are constructed by balancing the energy in a control volume.

For the solid regions, i.e. bipolar plate, fins and GDLs, the governing equation of heat transfer is represented as:

$$
\nabla^{2} T_{s}=0
$$

For the fluid regions, the governing equation of heat transfer is described as:

$$
\frac{\partial T_{f}}{\partial t}+u \cdot \nabla T_{f}=\alpha_{f} \nabla^{2} T_{f}
$$

The membrane and catalyst layer are considered as a homogeneous surface heat source, and the heat flow density is given by

$$
q=\lambda \Delta T
$$

\subsection{Boundary conditions}

This paper has investigated the influences on the cooling performance with different structures, different cooling air inlet velocities and different thermal conductivities of bipolar plate and fins.

In models, it is assumed continuity at all internal boundaries. The velocity and temperature of the feeding and cooling gases are given at the inlets. Within the active area a constant heat flux is given at the top surfaces of the both GDLs. The contact faces between

\begin{tabular}{|c|c|}
\hline Item & Value \\
\hline Electrical power of the fuel cell(W) & 120 \\
\hline Heat generation of the fuel cell(W) & 120 \\
\hline Active Area $\left(\mathrm{cm}^{2}\right)$ & 250 \\
\hline Length of the bipolar plate $(\mathrm{mm})$ & 251 \\
\hline Width of the bipolar plate(mm) & 163 \\
\hline Thickness of the bipolar plate(mm) & 3.5 \\
\hline Thickness of the fins(mm) & 1 \\
\hline Heat exchange area per fin $\left(\mathrm{m}^{2}\right)$ & $1.956 \mathrm{e}-2$ \\
\hline Cooling medium & Air \\
\hline Heat flux per GDL top surface $\left(\mathrm{W} \mathrm{m}^{-2}\right)$ & 2400 \\
\hline Anode gas inlet mass flow $\left(\mathrm{kg} \mathrm{s}^{-1}\right)$ & $2.9 \mathrm{e}-6$ \\
\hline Anode gas inlet temperature(K) & 368 \\
\hline Anode gas outlet pressure( $\mathrm{Pa})$ & 0 \\
\hline Cathode gas inlet mass flow $\left(\mathrm{kg} \mathrm{s}^{-1}\right)$ & $1.97 \mathrm{e}-4$ \\
\hline Cathode gas inlet temperature(K) & 368 \\
\hline Cathode gas outlet pressure $(\mathrm{Pa})$ & 0 \\
\hline Cooling Air inlet velocity $\left(\mathrm{m} \mathrm{s}^{-1}\right)$ & $10 / 20 / 30$ \\
\hline Cooling Air inlet temperature(K) & 298 \\
\hline GDL density $\left(\mathrm{kg} \mathrm{m}^{-3}\right)$ & 440 \\
\hline $\begin{array}{l}\text { GDL thermal conductivity, through } \\
\text { plane }\left(\mathrm{W} \mathrm{m}^{-1} \mathrm{~K}^{-1}\right)\end{array}$ & 1.7 \\
\hline GDL thermal conductivity, in plane( $\mathrm{W} \mathrm{m}^{-}$ & 23 \\
\hline GDL specific heat $\left(\mathrm{J} \mathrm{kg}^{-1} \mathrm{~K}^{-1}\right)$ & 840 \\
\hline Bipolar plate and fins density $\left(\mathrm{kg} \mathrm{m}^{-3}\right)$ & 1400 \\
\hline $\begin{array}{l}\text { Bipolar plate and fins conductivity(W m- } \\
\qquad 1 \mathrm{~K}-1)\end{array}$ & $20 / 50 / 100$ \\
\hline $\begin{array}{c}\text { Bipolar plate and fins specific heat }\left(\mathrm{J} \mathrm{kg}^{-}\right. \\
\left.{ }^{1} \mathrm{~K}^{-1}\right)\end{array}$ & 935 \\
\hline
\end{tabular}
the fluid domain and solid domain are coupled. All other out walls are assumed to be adiabatic.

The detailed geometry parameters are listed in Table 1.
Table 1 Parameters for numerical analysis

\subsection{Numerical procedure}

In the simulation, a three-dimensional, single-phase, non-isothermal and heat transfer model is adopted and implemented into a commercial computational fluid dynamics (CFD) package, FLUENTTM, in order to investigate the temperature distribution on the active area of MEA. The solution procedure is based on SIMPLE algorithm with algebraic multigrid (AMG) method [12]. The solution is assumed to converge if the residuals for the velocity are all under 0.001 and the residual for energy is less than 0.000001 . 


\section{Results and discussion}

\subsection{Cooling effect with different cooling modes}

As shown in Figure 3, there are two types of structure, of which fins are constructed at either the longer or the shorter borders of the bipolar plates. According to the different cooling air inlet positions and flow routes, they can be divided into four cooling modes, i.e. mode A, mode B, mode C and mode D. The coolant flow rates and the heat exchange area of those four modes are all the same.
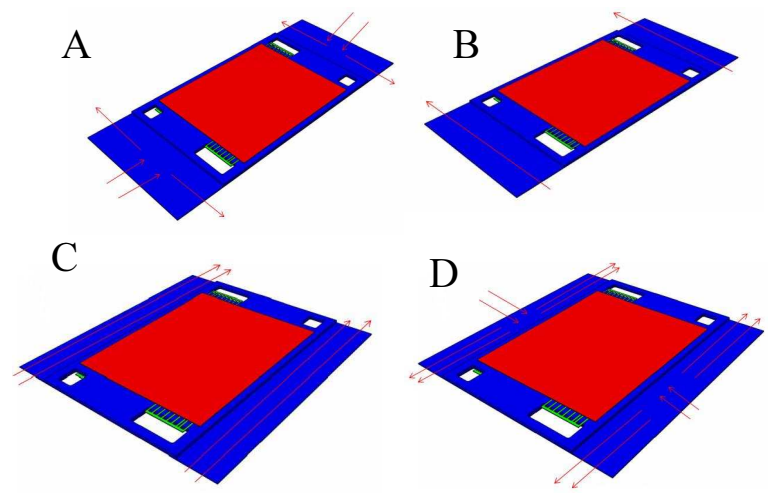

Figure3 Models of different cooling modes

In the simulations, the conductivity of bipolar plate and fins is $100 \mathrm{~W} \mathrm{~m}-1 \mathrm{~K}-1$, and the cooling flow velocity is $20 \mathrm{~m} \mathrm{~s}-1$. The temperature distributions on the active area under different cooling modes are shown in Figure 4.

It can be seen that the temperature distribution on the active area of mode $\mathrm{C}$ and $\mathrm{D}$ is more homogeneous than that of mode A and B. The table 2 shows that both of the average temperature and highest temperature of mode D is the lowest in the four modes. That means, with the same heat exchange area and coolant flow rate, the cooling effect of mode $\mathrm{D}$ is better than the others.
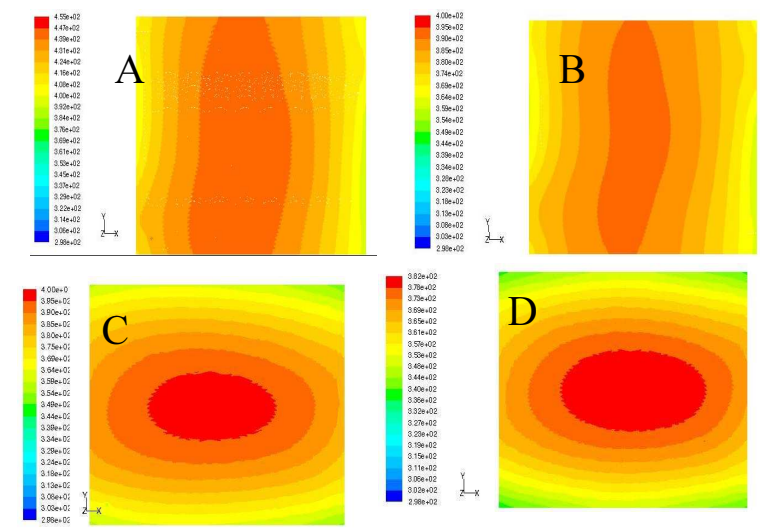

Table 2 Indexes of temperature distribution with different cooling modes

\begin{tabular}{cccc}
\hline $\begin{array}{c}\text { Cooling } \\
\text { mode }\end{array}$ & $\begin{array}{c}\text { Average } \\
\text { temperature } \\
(\mathrm{K})\end{array}$ & $\begin{array}{c}\text { Highest } \\
\text { temperature } \\
(\mathrm{K})\end{array}$ & $\begin{array}{c}\text { Standard } \\
\text { deviation of } \\
\text { temperature } \\
\text { distribution(K) }\end{array}$ \\
\hline Mode A & 431.2 & 445.7 & 12.5 \\
Mode B & 385.0 & 395.2 & 11.2 \\
Mode C & 382.7 & 393.8 & 10.5 \\
Mode D & 366.8 & 381.7 & 10.3 \\
\hline
\end{tabular}

\subsection{Cooling effect with different cooling flow velocities}

The cooling air flow velocity is an important parameter for the cooling system design, which can determine the type and the power of the cooling fan. Table 3 lists the cooling effect at different cooling air inlet velocities under mode $\mathrm{C}$. The results illustrate that the temperature declines with the cooling flow velocity increasing.

Table 3 Indexes of temperature distribution with different cooling flow velocities

\begin{tabular}{|c|c|c|}
\hline $\begin{array}{l}\text { Flow } \\
\text { velocity } \\
\left(\mathrm{m} \mathrm{s}^{-1}\right)\end{array}$ & $\begin{array}{c}\text { Average } \\
\text { temperature }(\mathrm{K})\end{array}$ & $\begin{array}{c}\text { Highest } \\
\text { temperature(K) }\end{array}$ \\
\hline 10 & 399.9 & 415.5 \\
\hline 20 & 382.7 & 393.8 \\
\hline 30 & 373.9 & 388.5 \\
\hline
\end{tabular}

\subsection{Cooling effect with different thermal conductivities}

Traditionally, the most widely used materials for bipolar plate are the graphite/polymer composites, which are ideal in terms of corrosion resistance and conductivity [13, 14]. Because of high mechanical strength and easily forming, metal such as aluminum, stainless steel becomes a new option as the bipolar plate materials [15]. Due to different properties of these materials, the thermal conductivity varies widely. The temperature distribution's indexes with different thermal conductivities under mode $\mathrm{C}$ are presented in table 4 . It shows that the cooling effect improves with the increasing of the bipolar and fins thermal conductivity, and the temperature decreases obviously and the temperature distribution becomes more homogeneous.

Figure 4 Temperature distributions on the active area under mode A, B, C, D, respectively 
Table 4 Indexes of temperature distribution with different thermal conductivities

\begin{tabular}{cccc}
\hline $\begin{array}{c}\text { Thermal } \\
\text { conductivity } \\
\left(\mathrm{W} \mathrm{m}^{-1} \mathrm{k}^{-1}\right)\end{array}$ & $\begin{array}{c}\text { Average } \\
\text { temperature }\end{array}$ & $\begin{array}{c}\text { Highest } \\
\text { temperature }\end{array}$ & $\begin{array}{c}\text { Standard } \\
\text { deviation of } \\
\text { temperature } \\
\text { distribution }\end{array}$ \\
\hline 20 & 500.4 & 562.5 & $(\mathrm{~K})$ \\
50 & 418.1 & 445.4 & 19.6 \\
100 & 382.7 & 393.8 & 10.5 \\
\hline
\end{tabular}

\section{Conclusions}

Three-dimensional fluid flow and heat transfer analysis of an elevated temperature PEMFC cooling structure was carried out using CFD software FLUENTTM. The cooling performance of different cooling modes, different cooling air inlet velocities and different thermal conductivities were obtained and compared.

For air cooling design, mode D is the best choice, by which excessive heat can be removed more effectively than others. Furthermore, increasing the cooling air inlet flow rate and the thermal conductivity of the bipolar plate and fins can improve the cooling performance and achieve more homogeneous temperature distribution.

The experimental results of these fluid flow and heat transfer in the elevated temperature PEMFC models are not readily available to compare the simulation results. In the next step, experimental works will be done with purpose of validation test of the modeling and simulation results. As an important measure, thermocouples will be employed to verify the temperature distribution inside the cell.

\section{Acknowledgment}

The authors would like to thank funding from China Ministry of Science and Technology (grant number: 2008AA050403). Many thanks to Bing LI, Zhiyong LI and Jing FU for providing good advise supports and discussions.

\section{References}

[1] J. Larminie and A. Dicks, Fuel cell systems Explained, Second Edition, West Sussex: Wiley, 2002.

[2] G.Karimi, J.J.Baschuk and X.Li. Performance analysis and optimization of PEM fuel cell stacks using flow network approach . Journal of Power Sources, Vol. 147, No. 1-2, Sept. 2005, pp: 162-177
[3] J.L. Zhang, Z. Xie, J.J. Zhang, Y.H. Tang, C.J. Song, T. Navessin, Z.Q. Shi, D.T. Song, H.J. Wang, D.P. Wilkinson, Z.S. Liu, S. Holdcroft, High temperature PEM fuel cells, Journal of Power Sources, Vol. 160, No.2, Oct.2006, pp:872-891.

[4] F.C. Chen, Z. Gao, R.O. Loutfy and M. Hecht, Analysis of Optimal Heat Transfer in a PEM Fuel Cell Cooling Plate, Journal of Fuel cells, Vol. 3, No.4, Jan.2004, pp:181-188.

[5]Y.L.Tang, A.M.Karlsson, M.H.Santare, M.Gilbert, S.Cleghorn and W.B.Johnson, An experimental investigation of humidity and temperature effects on the mechanical properties of perfluorosulfonic acid membrane, Materials Science and Engineering, Vol. 425, No.1-2, Jun.2006, pp:297-304

[6] L,J.Bonville, H.R.Kunz, Y.song, A.Mientek, M. Williams, A.Ching and J.M. Fenton, Development and demonstration of a higher temperature PEM fuel cell stack, Journal of Power Source, Vol. 144, No.1, Jun.2005, pp:107-112

[7] J.O.Jensen, S.Y.Andersen, T.D.Rycke, M.Nilsson, and T.Christensen, High Temperature PEM Fuel Cell Final report, PSO project:4760, 2006

[8]J.Burfeind, G.Bandlamudi, F.Fliusch, C.Siegel and A. Heinzel, Kompakte 140 Wel HT-Brennstoffzelle zum Betrieb mit Methanolreformat, 4. Deutscher Wasserstoff Congress, Feb.2008

[9]J.Scholta, M.Messerschmidt, L.Jorissen and C.Hartnig, Externally cooled with high temperature polymer electrolyte membrane fuel cell stack, Journal of Power Source, Vol. 190, No.1, May. 2009, pp:83-85

[10]P.Pfeifer, C.Wall, O.Jensen, H.Hahn and M.Fichtner, Thermal coupling of a high temperature PEM fuel cell with a complex hydride tank, International Journal of Hydrogen Energy, Vol. 34, No.8, May.2009, pp:3457-3466.

[11]J.Scholta, W.B.Zhang, L.Joerissen and W.Lehnert, Conceptual Design for an Externally Cooled HT-PEMFC Stack, The Electrochemical Society,Vol. 12, No.1, 2008, pp: 113-118

[12]Fluent Inc. FLUENT 6.2 Documentation. http://www.fluent.com, 2005.

[13]P.L. Hentall, J.B. Lakeman, G.O. Mepsted, P.L. Adcock and J.M. Moore, New materials for polymer electrolyte membrande fuel cell current collectors, Journal of Power Sources, Vol. 80, No. 1-2, Jul.1999, pp: 235-241.

[14] J. Scholta, B. Rohland, V. Trapp and U. Focken, Journal of Power Sources, Investigations on novel low-cost graphite composite bipolar plates, Vol. 84, No.2, Dec.1999, pp: 231-234.

[15] A.Pozio, F.Zaza, A. Masci and R.F.Silva, Bipolar plate materials for PEMFCs: A conductivity and stability study, Journal of Power Source, Vol. 179, No.2, May 2008, pp : 631639.

\section{Author}

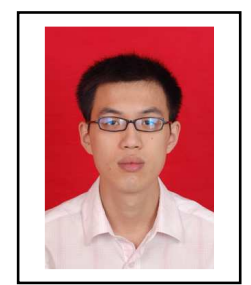

Master Candidate. Xiaoliang Zheng School of Automotive Studies, Tongji University, 4800 Cao'an Road, Shanghai, $\mathrm{P}$ R China, 201804 Tel:+86-21-6958-9337 Fax: +86-21-6958-9121 Email:morgen_zh@yahoo.com.cn

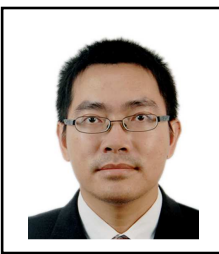

Ph.D. Daijun Yang

School of Automotive Studies, Tongii University, 4800 Cao'an Road, Shanghai, P R China, 201804 Tel:+86-21-6958-3891

Fax: +86-21-6958-9121

Email: yangdaijun@126.com 


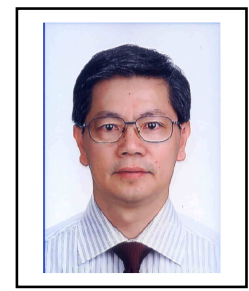

Professor. Jianxin Ma

School of Automotive Studies, Tongji

University, 4800 Cao'an Road, Shanghai, $\mathrm{P}$

R China, 201804

Tel:+86-21-6958-9480

Fax:+86-21-6958-9121

Email:jxma@tongji.edu.cn 